\title{
Ensuring the Economic Security of Ukraine in the Aspect of the Association Agreement Between the EU
}

\author{
By Leonid Mohilevskyi ${ }^{1}$, Viktoryia Fursa ${ }^{2}$, Iryna Sievidova ${ }^{3}$, Mykola Komziuk ${ }^{4}$, \\ Olga Khloponina-Gnatenko ${ }^{5}$, Daria Pidkopai ${ }^{6}$
}

\begin{abstract}
The study characterizes economic security as a set of conditions that are necessary to ensure the normal economic development of the country and restore the gap in development in comparison with European countries during Ukraine's integration into the EU. It is shown that ensuring economic security is an important function of the state. The problem of economic security arises not only from the definition of the internal policy of the state, but also determines the issues of foreign strategy. The necessity of calculating the main safety criteria has been proved, allowing to anticipate possible dangers, determine potential current and future damage and take preventive measures. Stability and development require a dynamic approach to solving the problem of economic security. This is mainly due to the rapid change in indicators of economic security and indicators with a change in the operating conditions of international, political, economic, market and other systems. The urgency of solving the problems of economic security is based on the need to get rid of the dependence of the national economy on the level of competition in world markets. This is due to the emergence of serious economic risks arising when the actual values of economic security indicators go beyond the threshold levels. The current level of economic security has been investigated by calculating indicators that characterize all sectors of the national economy. The most problematic areas requiring immediate response have been identified. The presented methodology for calculating the integral indicator of the economic security of Ukraine quite accurately describes the current state of the national economy and can be practically applicable to domestic and foreign government bodies in the analysis of critical vulnerabilities of national economic security.
\end{abstract}

Keywords: economic security, national economy, indicators, integral indices of economic security, economic interests, national security

\section{Introduction}

Broadly speaking, the national economic security is determined by the quantity of available resources and level of development. However, even this broad definition does

$\mid{ }^{1}$ Doctor of Legal Sciences, Professor, Vice-rector of Kharkiv National University of Internal Affairs, Ukraine; Corresponding Author

${ }^{2}$ Candidate of Economic Sciences, Associate Professor of the Department of Legal Support of Economic Activity, Kharkiv National University of Internal Affairs, Ukraine

${ }^{3}$ Doctor of Economic Sciences, Professor of the Department of Legal Support of Economic Activity, Kharkiv National University of Internal Affairs, Ukraine

${ }^{4}$ Candidate of Legal Sciences, Senior Lecturer of the Department of Tactical and Special Physical Training, Kharkiv National University of Internal Affairs, Ukraine

${ }^{5}$ Candidate of Economic Sciences, Associate Professor of the Department of Entrepreneurship, Trade and Exchange Activity, Kharkiv Petro Vasylenko National Technical University of Agriculture, Ukraine

6 Candidate of Legal Sciences, Senior Lecturer of the Department of Law-Enforcement Activity and Policeistics, Kharkiv National University of Internal Affairs, Ukraine 
not in fact encompass all aspects of economic security. The economic security cannot be considered statically, apart from the national security and national interests. It includes the current national economic policy, medium-term and long-term goals, level of state integration in both international trade and international relations in general. The relationship between the economic security and degree of economic integration determines the level of economy's vulnerability. Thus, the ability of national economy to pursue national interests is determined by the level of its vulnerability. It is possible to regard it as a ratio of advantages to disadvantages of the national economy in the context of international economic climate, domestic social and political environment. This determines the ability of national economy to respond to internal and external challenges. The global hierarchical restructuring towards strengthening the role of international integrated entities (EU, ASEAN, NAFTA), especially due to their geographical expansion and acquisition of new important functions, has become an important aspect of modern global economy. Their mission is not only to ensure competitiveness of the member countries by managing international monetary relations and promoting foreign investments or international sales, but to attend to a wide range of economic and noneconomic factors (Taranych, 2016).

Ukraine's integration into the European Union significantly affects the very structure of society, and the integration process is not manifest just in economic factors. The integration process lies deeper than the relationship within international financial or market institutions and organizations. The process of Ukraine's integration into the EU determines the national economy restructuring towards the already existing rules of interaction. This process reveals the unprotected state of national economy, which is supported by compliance with the EU regulations and restrictions. At the present stage, Ukraine's economy is characterized by a low level of economic security because of a delayed accession to the EU, as well as a wider adoption of its regulations.

The deep restructuring of national economy and large-scale re-orientation of economic relations make the national economy rather unstable, dependent on the policies of large international financial institutions or intergovernmental bodies. However, the concept of economic security correlates poorly with the modern concept of economic neoliberalism. The main reason is that to ensure economic security, the national governments have to prevent, prohibit or restrict the activities of economic entities which may violate this security. Thus, they conflict with the interests of major international market forces and certain financial organizations. However, the concept of national economic security is the ideological foundation of the national policy development.

\section{The Market Research Conducting - A Literature Review}

For historical reasons, major research in the field of economic security was initiated in the United States in the early twentieth century under the conditions of global economic crisis. All most developed countries gradually joined this research in the second half of the twentieth century (Tamošiūnienè \& Munteanu, 2015).

According to the researchers, the interest in economic security in the former Soviet Union resulted from its problematic transition to a market economy, while this research focused on various aspects of foreign policy in the Western countries. Thus, the understanding of 
economic security largely depends on the socio-economic conditions of its development. Therefore, the differentiation of these conditions later resulted in a different interpretation of economic security concept (Lima \& Snower, 2020).

Like security in general, the economic security has dramatically changed its content and characteristics. At the beginning of its development the concept of economic security included individual, regional and national levels, but with capitalism strengthening its position, it added the corporate level (Wolfers, 1952). By the end of the twentieth century, there were already five levels of economic security: international, national, regional, corporate and individual (Hager, 1980). At the present stage, the global level has been added to them (unlike the international one, having countries as subjects, this one deals with international non-governmental structures, transnational corporations and organizations created and functioning under the aegis of different states) (Leszczyński, 2019).

According to the paper (Gębska, 2018), the economic security should be regarded as a state of the national economy, ensuring its resistance to internal and external factors, which disrupt the ordinary course of social reproduction, undermine the achieved standard of living and increase social tension, thus threatening the existence of the state.

According to another point of view, the economic security implies a certain state of the economy characterized by economic sovereignty and competitive environment. The subjects of economic relations, including public authorities and economic agents, ensure sustainable economic growth and sustainable economic development. In general, it results in appropriate satisfaction of the needs of people, society and state and rational economy management; national and international protection of economic interests from the internal and external threats and impact of negative factors, as well as economic area integrity (Andruseac, 2015).

Thus, economic security is an important component of national security, which allows access to resources, finances and markets, maintains an acceptable level of welfare and state power and ensures a dynamic balance of other security components (Mihai \& Pişleag, 2013). Some economists consider economic security to be the basis for the functioning of society. Emphasizing its utmost importance, they claim that the external and internal factors may lead to a situation where the economic security will play the role of national security, as it will determine the country's position in the global economy (Repciuc, 2008). Modern specialized studies name the basic elements of economic security as follows (Napalkova, 2000):

- forecasting and assessment of real and possible threats to economic security;

- development of the main activities in this area;

- external and internal legal regulations;

- development, preparation and maintaining readiness of forces and means;

- adequate planning of the use of forces and means in case of a direct impact of destructive factors (threats);

- formation and improvement of governing bodies and management techniques both by the subject's economic security system and its other bodies, parts, departments, technical systems;

- planning of activities of the management bodies and economic security subject under the direct impact of a destructive factor (threat); 
- training of economic security personnel for the activities under the impact of a destructive factor, if any;

- reservation of appropriate material supplies and other strategic stocks to ensure economic security;

- planning and holding of the subject's civil defense activities related to its economic security, etc.;

- immediate equipping of the territory and technical means;

- ensuring the protection of secret information;

- application of science to ensure the subject's economic security;

- coordination of activities of the subject's governing bodies in case of an impact of destructive factors;

- adequate financing and control over the efficient spending of allocated funds;

- cooperation with other subjects to ensure collective economic security.

According to another point of view, the country's economic security has the following internal structure (Bai, 2002):

economic independence (the country's ability to control national resources, certain level of production efficiency and product quality, products' global competitiveness on equal competitive footing, cooperation and scientific and technological achievement sharing at the international level);

- stability and robustness of the national economy (protection of all forms of property, creation of safe conditions and guarantees for entrepreneurs, factor management to avoid destabilization);

- ability to develop and make progress (creation of a favorable investment climate, constant modernization of production facilities; professional and general training of employees, their education, etc.).

In this respect, the national economy influences and at the same time is influenced itself by the level of economic development of the branches of national economy and enterprises. Thus, the measures taken to improve economic security can be considered at two different levels. At the national level: to accelerate the government negotiations aimed at resisting discriminatory laws and Western policies; regulate the activities of antidumping entities for the purpose of trade protection; provide consulting assistance to enterprises; establish an early warning mechanism and provide advisory services for international trade disputes. At the corporate level: to completely prepare for anti-dumping investigations; ensure fairness and competitiveness of trade; initiate diversification processes. Undoubtedly, it justifies the engagement with potential threat detection and ensuring the economic security.

\section{Study of Methodological Approaches to the Assessment of Economic Security Level}

There are many definitions of economic security, because the concept itself is quite broad and even ambiguous. The economic security can be considered in relation to different categories of security subjects: producers, consumers, owners of production factors, the state itself (Letiche, 1969; Nee \& Swedberg, 2008; Harrison, 2002). The evolution of the concepts of national economic security is connected with the economic 
theory typology and evolution, as well as analysis of national economic development (Tab. 1).

Table 1. Concepts of the national economic security

\begin{tabular}{|c|c|c|c|c|c|}
\hline Concept & $\begin{array}{l}\text { Formatio } \\
\text { n time }\end{array}$ & Founders & Goals & $\begin{array}{l}\text { Subjects of } \\
\text { influence }\end{array}$ & Subjects of influence \\
\hline Mercantilism & 1650 & $\begin{array}{l}\text { Veit Ludwig von } \\
\text { Seckendorff }\end{array}$ & Growing wealth domestically & $\begin{array}{l}\text { Economic } \\
\text { institutions }\end{array}$ & $\begin{array}{l}\text { Foreign trade, unequal } \\
\text { exchange }\end{array}$ \\
\hline Cameralism & 1840 & $\begin{array}{l}\text { Georg Friedrich } \\
\text { List }\end{array}$ & Economic independence & $\begin{array}{l}\text { Countries } \\
\text { catching up } \\
\text { development }\end{array}$ & $\begin{array}{l}\text { Protectionist economic } \\
\text { policy, comprehensive } \\
\text { development of the } \\
\text { national economy }\end{array}$ \\
\hline $\begin{array}{l}\text { Keynesian } \\
\text { economics }\end{array}$ & 1930 & $\begin{array}{l}\text { John Maynard } \\
\text { Keynes }\end{array}$ & Economic and social stability & $\begin{array}{l}\text { The developed } \\
\text { countries }\end{array}$ & $\begin{array}{l}\text { State regulation of } \\
\text { production, employment } \\
\text { and money circulation }\end{array}$ \\
\hline $\begin{array}{c}\text { far-left political } \\
\text { theory }\end{array}$ & 1970 & $\begin{array}{l}\text { Raul Prebisch, } \\
\text { Celso Furtado }\end{array}$ & Human values & $\begin{array}{l}\text { Developing } \\
\text { countries }\end{array}$ & $\begin{array}{c}\text { Planning from below, } \\
\text { limiting the consumption } \\
\text { of some to the required } \\
\text { level }\end{array}$ \\
\hline $\begin{array}{l}\text { Institutional } \\
\text { economics }\end{array}$ & 1980 & Hernando de Soto & $\begin{array}{l}\text { "Board of law", protection } \\
\text { of property rights }\end{array}$ & $\begin{array}{l}\text { Developing } \\
\text { countries }\end{array}$ & $\begin{array}{c}\text { Reducing registration } \\
\text { procedures and payments, } \\
\text { fighting corruption and } \\
\text { bureaucracy }\end{array}$ \\
\hline \begin{tabular}{|c|} 
Neo- \\
institutionalis \\
$\mathrm{m}$
\end{tabular} & 1990 & Ronald Coase & $\begin{array}{c}\text { Transaction cost } \\
\text { optimization }\end{array}$ & $\begin{array}{c}\text { Organizations, } \\
\text { corporations }\end{array}$ & $\begin{array}{l}\text { Introduction of informal } \\
\text { restrictions, formal rules, } \\
\text { enforcement mechanisms }\end{array}$ \\
\hline
\end{tabular}

In the context of this study, the economic security is defined as a set of conditions necessary to ensure the normal course of the country's economic development and restore the development gap between the European countries and Ukraine integrating into the EU.

It is impossible to separate modern economic factors which can ensure security from the irreversible process of globalization, which promotes both cooperation and competition in the field of energy, resources and markets. The processes of globalization have accelerated the economic, technological, cultural and political integration, along with the democratic governance, economic dynamism and market economy, respect for human rights and development of communications. They have also increased and complicated economic relations and interdependencies between states, as well as between national and global economies. Moreover, the acceleration of globalization has also increased security interdependence and synergies; if managed wisely, it can have a positive impact on the stability of international relations. Therefore, achieving a certain level of security in the context of globalization depends on the ability of the state to aggregate resources within the country and to obtain or maintain access to external economic resources (Băhnăreanu, 2006). In the course of Ukraine's economy transformation, the domestic enterprises have to face many non-routine situations and non-standard issues with no ready-made solution patterns. However, it is possible to determine tools that can limit the negative impact of unregulated market by means of regulating it or adapting to it (Sievidova, 2018).

Ukraine's economic transformation can go on, only if combined with the increased real income and higher living standards which ensure social support for reforms. The unreasonable government expenditures have significantly undermined and are undermining the economic and political balance. An obvious relationship between of the 
rate of development of branches of economy and quality changes, introduction of innovations in the production techniques, large market availability, and general improvement of labor and production organization can be traced (Sievidova \& Plihun, 2018).

To achieve the average European level of production, the rational development of production sector is needed. However, solid investments are needed to create conditions for economic growth and achieving an appropriate level of Ukraine's economic security. As to the agriculture taken alone, according to some estimates, the total amount of capital investments was less than 2.0 billion US dollars (prices of 2019) in 2020, which is 5\% less than in 2019 and 17-20\% less than in 2017 and 2018. Thus, a significant increase in foreign investment is absolutely necessary.

But attracting foreign direct investment requires proper public debt management, reducing inflation and external debt, creating a favorable business environment and legal framework for market economy development (Xiao, \& Park, 2018). An active participation in the international trade and access to resources, finance and markets is the most important factor of economic security related to economic stability, which is necessary to achieve an appropriate security status (Wehre \& Pohl, 2016). In general, active investment in the country's economy is a necessary condition for maintaining an acceptable level of welfare and economic development (Gribincea, Golovataia, Brovca, 2014).

\section{Calculation of Typical Values of the Economic Security Indicators}

The acceleration of the international economy globalization results in the acquisition of certain preferences together with the emergence of new risks, costs and general recession of national economy. At the present stage of global economy development, it is essential to rank the states according to the level of their economic development and their role in the global economy. The continuous development of world economic systems gives one-sided advantages to economically developed countries. The authors of the study (Milberg \& Winkler, 2009) show that advanced economy often has a greater impact on income than cheap labor and production or management innovations. Therefore, the countries with underdeveloped economies are not able to protect their interests on equal footing. Understanding these consequences implies reconsideration of methods of ensuring the economic security.

Ensuring an economic advantage in world markets by determining the best business strategy for each enterprise selling products in the market is a must (Sievidova, 2018). First of all, ensuring an appropriate level of economic security requires reviewing the methods for the assessment of economic security level.

Thus, the world's high degree of economic interdependence implies a better competitive environment for businesses; transformation of the state's economic functions and delegation of some of them to the global market; extending the spheres of influence beyond the national borders according to the new rules of global economic activities; making fundamental changes in the structure of national economy and creating a new environment for the national development in general; acceleration of international integration and interaction of national economies, which becomes the most important factor in their functioning (Kyrylov, 2016). 
In the current sense of economic security, it has the following components: production, demographic, energy, foreign economic, investment and innovation, macroeconomic, food, social, financial security components (Eurostat, 2019).

Industrial security is a state of the country's production sector, which ensures the most efficient use of the country's production facilities, their modernization and extended reproduction, increase in production innovations and increased level of the national economy competitiveness.

Demographic security is a state of protection of the state, society and labor market from demographic threats, which ensures the development of Ukraine with due regard to the balanced demographic interests of the state, society and the individuals in accordance with the constitutional rights of Ukrainian citizens.

Energy security is a state of economy promoting the efficient use of the country's energy resources, availability of a sufficient number of energy producers and suppliers in the energy market, as well as availability, differentiation and environmental friendliness of energy resources.

Foreign economic security is a state of compliance of foreign economic activities with the national economic interests; it ensures mitigation of the country's losses from negative external economic factors and creation of favorable conditions for the development of national economy due to its active participation in the division of labor on a world scale. Investment and innovation security is a state of the country's economic environment, which encourages domestic and foreign investors to invest in expansion of the country's production volume, promotes high-tech production, as well as integration of research and production to increase efficiency and specialization of the national economy in products with a high added value.

Macroeconomic security is a state of the economy ensuring balanced macroeconomic reproduction ratios.

Food security is a state of the country's food production which fully meets the needs of each member of society in food of adequate quality, provided it is balanced and available to each member of society.

Social security is a state of the country's development which enables the country to ensure a decent and high-quality standard of living regardless of age, gender, income, and promote the development of human capital assets being the most important component of the country's economic potential.

Financial security is a state of the country's financial system, ensuring the financial conditions necessary for the country's stable socio-economic development, country's resilience to financial shocks and imbalances, as well as creating conditions for maintaining the integrity and unity of the country's financial system. The country's main economic security indicators are calculated according to these components. The list of used indicators is to be created based on the principles of representativeness, reliability and information availability. In accordance with the "Guidelines for calculating the level of economic security of Ukraine", the indicators are normalized using a linear function so that the typical values of indicators fall into intervals comparable in size.

The range of typical values of economic security levels is determined by the following types of indicators. The type $\mathrm{C}$ indicator is a stimulant, $\mathrm{i}$. e. there is a direct relationship between the stimulant indicator and the integral estimate. The type B indicator is a 
disincentive, i. e. there is an inverse relationship between the disincentive indicator and the integral estimate (Fig. 2).

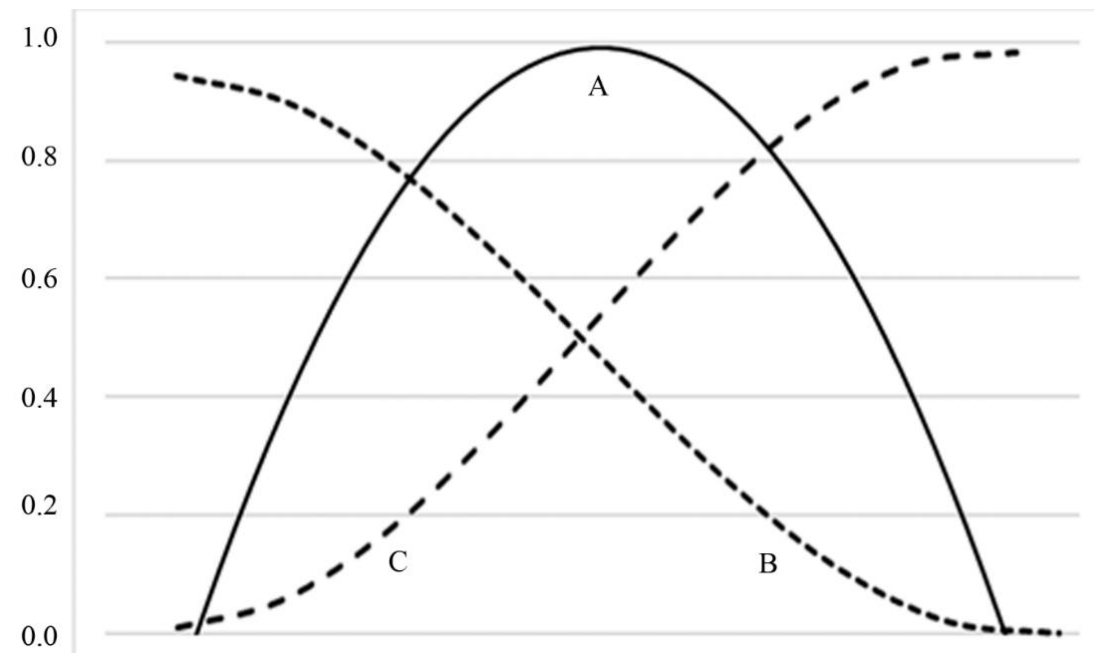

Fig. 2. Range of typical values of economic security levels for the different types of indicators.

So, if the indicator is a stimulator, the following function is used:

$z_{i}=\frac{x_{i}}{k_{\text {norm }}}$ if $x \in C$ and $k_{\text {norm }} \geq x_{\text {max }}$,

where $x_{i}$ is the indicator's empirical value; $x_{\max }$ is the indicator's maximum value; $k_{\text {norm }}$ is a normalization factor.

If the indicator is a stimulator, the following function is used:

$z_{i}=\frac{x_{i}}{k_{\text {norm }}}$ if $x \in C$ and $k_{\text {norm }} \leq x_{\text {min }}$,

where $x_{i}$ is the indicator's empirical value; $x_{\min }$ is the indicator's minimum value; $k_{\text {norm }}$ is a normalization factor.

If the indicator changes according to type $\mathrm{A}$, it is a stimulant until it reaches a certain value, and if it continues to increase, it becomes a disincentive. For the left part, the computations are performed according to Formula (1) and for the right part (a disincentive), further computations are performed according to Formula (2).

From the point of view of ensuring the economic security, we believe that first of all the following cumulative indicators must be taken into account:

- average ratio of the gross added value of Ukrainian industry to the gross added value of the industry of particular European countries (X1);

- number of population (X2);

- share of the elderly population in the total population (X3);

- demographic burden of the incapacitated population on the able-bodied population (X4);

- ratio of investment in the fuel and energy sector to gross domestic product (X5);

- import-export coverage ratio (X6);

- share of imports in the country's domestic consumption (X7);

- ratio of the value of newly introduced fixed assets to the volume of capital investment (X8); 
- ratio of the size of Ukrainian economy to the world's GDP (X9);

- Ukraine's current balance of payments (X10);

- ratio of Ukraine's GDP per capita to the average value in the EU countries (X11);

- grain production per person per year (X12);

- ratio of the average monthly nominal wage to the subsistence minimum per able-bodied person (X13);

- ratio of the average monthly wage (average value per hour) in the EU countries to that of Ukraine (X14);

- ratio of the government plus government-guaranteed debt to GDP (X15);

- ratio of the gross external debt to GDP (X16);

- ratio of the national deficit/surplus to GDP (X17);

- index of the change in the national currency to US dollar exchange rate (X18).

This number of indicators, some of which are stimulators and others are disincentives, is characteristic of any more or less complex task of studying business activities.

The following functions are used to calculate the economic security indicators:

$X 1=0,34 P+0,16 G+0,28 S p+0,22 I t$,

where $P$ - (GVA of Ukrainian industry, in 2007 prices, million UAH / average annual exchange rate of UAH to EUR in 2007) / GVA of Polish industry, in 2007 prices, million EUR x 100;

G - (GVA of industry of Ukraine, in 2007 prices, million UAH / average annual exchange rate of UAH to EUR in 2007) / GVA of German industry, in 2007 prices, million EUR x 100

Sp - (Airborne industry of Ukraine, in 2007 prices, million UAHs / average annual exchange rate of UAH to EUR in 2007) / Airborne industry of Spain, in 2007 prices, million EUR x 100;

It - (Airborne industry of Ukraine, in 2007 prices, million UAHs / average annual exchange rate of UAH to EUR in 2007) / Airborne industry of Italy, in 2007 prices, million EUR x 100.

$X 2=K n / K p \times 100$,

where $K n$ is a number of available population of the period under analysis; $K p$ - the number of available population in 1990 , thousand people.

$X 3=(K m+K w) / K n \times 100$,

where $K m$ is a number of men aged 65 and older; $K w$ - the number of women aged 60 and older, thousand people.

$X 4=(Q p u+Q p o) / Q p w \times 100$,

where Qpu is a population under the age of able-bodied; Qpo - population over the age of able-bodied; $Q p w$ - population of working age, thousand people.

$X 5=K i / G D P \times 100$,

where $K i$ is a capital investment by type of economic activity "Production and distribution of electricity, gas and water", million UAH.

$X 6=\operatorname{Exp} / \operatorname{Imp}$,

where Exp is a volume of exports of goods and services; Imp - volume of imports of goods and services, million US dollars.

$X 7=\operatorname{Imp} /(\operatorname{Prod}+\operatorname{Exp}-\operatorname{Imp})$, 
where Prod is a production of goods and services, million UAH.

$X 8=C f a / I n v \times 100$,

where $C f a$ is a cost of new fixed assets put into operation; Inv - the capital investment, million UAH.

$X 9=(G D P / K d) / G D P w \times 100$,

where $K d$ is an average exchange rate of UAH to the US dollar; GDPw - the world gross domestic product, million US dollars.

$X 10=(S s v \times K d) / G D P \times 100$,

where $S s v$ is a current account balance, million USD.

$X 11=(K u k r / K e) / K e u \times 100$,

where Kukr is a ratio of GDP per capita in Ukraine, UAH; Ke - average exchange rate of UAH to EUR; Keu - the ratio of GDP per capita in the EU, EUR.

$X 12=V g / K n$,

where $V g$ is a production of grain and leguminous crops in the current period, thous. tons. $X 13=S a / L W$,

where $S a$ is an average monthly nominal wage for the relevant period; $L W$ - weighted average subsistence level per able-bodied person per month for the relevant period, UAH. $X 14=($ SHeu $/ \mathrm{SHu}) / \mathrm{Ke}$,

where $S H e u$ is an average monthly salary, calculated on average per hour, in EU countries, euro; $S H u$ - the average monthly salary, calculated on average per hour, in Ukraine, UAH. $X 15=P D / G D P \times 100$,

where $P D$ is an amount of public and guaranteed debt, million UAH.

$X 16=(E D \times K d) / G D P \times 100$,

where $E D$ is a gross external debt, million US dollars.

$X 17=B D / G D P \times 100$,

where $B D$ is a state budget deficit, million UAH.

$X 18=\mathrm{Kecp} /$ Kelp $\times 100$,

where Kecp is an official exchange rate of UAH to US dollar in the current period, the average for the period; Kelp - the official exchange rate of UAH to US dollar in the corresponding period last year, the average for the period.

We are going to calculate the current values of specified indicators; their comparison with the corresponding standard values enables analyzing various components of Ukraine's economic security. Calculation of cumulative indices for the particular sectors of economy and cumulative index of economic security in general:

For X1 by formula (3):

$\mathrm{X} 1=0,34 \times(((1306424,0 / 6,93)) / 435875,2) \times 100+$

$0,16 \times(188517,1 / 3106157,0) \times 100+0,28 \times(188517,1 / 1129110,0) \times 100+$

$0,22 \times(188517,1 / 1603736,0) \times 100=22,9$

For X2 by formula (4):

$\mathrm{X} 2=417132,8 / 51838,5 * 100=80,5$

For X3 by formula (5):

$\mathrm{X} 3=(3308,8+5358,3) / 41732,8 \times 100=20,8$

For X4 by formula (6):

$\mathrm{X} 4=(6824,1+8667,1) / 26241,6 \times 100=59,0$ 
For X 5 by formula (7):

$\mathrm{X} 5=78395,3 / 3974652,1 \times 100=1,97$

For X6 by formula (8):

$\mathrm{X} 6=1653780,0 / 1746660,0=0,95$

For X7 by formula (9)

$X 7=1957770,0 /(8370824,0+1957770,0-1653780,0) \times 100=22,6$

For X8 by formula (10):

$\mathrm{X} 8=437694,6 / 623978,9 \times 100=70,2$

For X9 by formula (11):

$\mathrm{X} 9=(3974652,1 / 25,8) / 87552440 \times 100=0,18$

For X10 by formula (12):

$\mathrm{X} 10=(-1115,6 \times 25,8) / 3974652,1 \times 100=-0,72$

For X11 by formula (13):

$\mathrm{X} 11=((94570 / 28,95)) / 28610 \times 100=11,4$

For X12 by formula (14):

$\mathrm{X} 12=75143 / 41732,8=1,8$

For X13 by formula (15):

$\mathrm{X} 13=9205 / 1971=4,7$

For X14 by formula (16):

$\mathrm{X} 14=((358,2 / 60)) / 28,95=14,4$

For X15 by formula (17):

$\mathrm{X} 15=1998275,4 / 3974652,1 \times 100=50,3$

For X16 by formula (18):

$\mathrm{X} 16=(121739,0 \times 25,8) / 3974652,1 \times 100=79,0$

For X17 by formula (19):

$\mathrm{X} 17=81201,0 / 3974652,1 \times 100=2,1$

For X18 by formula (20):

$\mathrm{X} 18=25,8 / 27,2 \times 100=94,9$

The following table contains the set of values of specified indicators and their threshold values to normalize the economic security indicators (Tab. 2).

Table 2. Main economic security indicators (as of 01.2020 )*

\begin{tabular}{|c|l|c|c|}
\hline $\begin{array}{c}\text { Integrated } \\
\text { indicators }\end{array}$ & Indicator name, unit of measurement & \multicolumn{2}{|c|}{ alue of the indicator } \\
\cline { 2 - 3 } X1 & $\begin{array}{l}\text { The average ratio of the gross value added of the Ukrainian } \\
\text { industry and the airborne forces of the industry of individual } \\
\text { European countries, percent }\end{array}$ & 20 & 22,9 \\
\hline X2 & Population size & 85 & 80,5 \\
\hline X3 & Share of the elderly population in the total population & 25 & 20,8 \\
\hline X4 & $\begin{array}{l}\text { Demographic load of the disabled population on the able- } \\
\text { bodied, percent }\end{array}$ & 55 & 59 \\
\hline X5 & $\begin{array}{l}\text { The ratio of investments in enterprises of the fuel and energy } \\
\text { complex to the gross domestic product, percent }\end{array}$ & 7 & 2 \\
\hline X6 & Coverage ratio by export of imports, times & 1,7 & 0,95 \\
\hline X7 & $\begin{array}{l}\text { Share of imports in domestic consumption of the country, } \\
\text { percent }\end{array}$ & 30 & 22,6 \\
\hline
\end{tabular}




\begin{tabular}{|c|c|c|c|}
\hline \multirow{2}{*}{$\begin{array}{l}\text { Integrated } \\
\text { indicators }\end{array}$} & \multirow{2}{*}{ Indicator name, unit of measurement } & \multicolumn{2}{|c|}{ Value of the indicator } \\
\hline & & critical & actual \\
\hline $\mathrm{X} 8$ & $\begin{array}{l}\text { The ratio of the value of the fixed assets introduced to the } \\
\text { volume of capital investments, percent }\end{array}$ & 55 & 70,2 \\
\hline $\mathrm{X} 9$ & The size of the Ukrainian economy, percent of world GDP & 0,15 & 0,18 \\
\hline $\mathrm{X} 10$ & $\begin{array}{l}\text { Current account balance of the balance of payments of } \\
\text { Ukraine, percent }\end{array}$ & -7 & $-0,72$ \\
\hline $\mathrm{X} 11$ & $\begin{array}{l}\text { The ratio of the volume of GDP per capita in Ukraine to the } \\
\text { average value in the EU countries, percent }\end{array}$ & 10 & 11,4 \\
\hline $\mathrm{X} 12$ & Grain production per capita per year, tons & 0,6 & 1,8 \\
\hline $\mathrm{X} 13$ & $\begin{array}{l}\text { The ratio of the average monthly nominal wage and the } \\
\text { subsistence minimum per one able-bodied person, times }\end{array}$ & 1,5 & 4,7 \\
\hline $\mathrm{X} 14$ & $\begin{array}{l}\text { The ratio of the average monthly wage, accrued on average per } \\
\text { hour, in the EU countries and in Ukraine, times }\end{array}$ & 5 & 0,21 \\
\hline $\mathrm{X} 15$ & Ratio of public and publicly guaranteed debt to GDP, percent & 60 & 50,3 \\
\hline $\mathrm{X} 16$ & Ratio of gross external debt to GDP, percent & 70 & 79 \\
\hline $\mathrm{X} 17$ & The ratio of the state budget deficit / surplus to GDP, percent & 10 & 2,1 \\
\hline $\mathrm{X} 18$ & $\begin{array}{l}\text { Index of changes in the official exchange rate of the national } \\
\text { currency against the US dollar }\end{array}$ & $90 ; 130$ & 94,9 \\
\hline
\end{tabular}

We have studied eighteen indicators for all sectors of national economy. After analyzing the economic security level according to these indicators, we can state that at the present stage, Ukraine is in the critical zone according to four of them. The recovery and use of labor resources is the most problematic issue. Besides, Ukraine is close to the critical zone according to at least six other indicators. As to the national economic security in general, its condition does not raise a serious concern. However, this does not remove the need to pay attention to its problematic aspects.

The cumulative indicator of corresponding economic security component is calculated according to the formula:

$I_{m}=\sum_{i=1}^{n}\left(W_{i} \times N V_{i}\right)$,

where $\mathrm{W}$ is a weighting coefficient of $\mathrm{T}$ indicator in the cumulative index of economic security component; $\mathrm{NV}$ is a normalized value of $\mathrm{T}$ indicator.

where $W$ is a weighting factor of the $i$-th indicator in the integrated index of the component of economic security; $N V$ - normalized score of the i-th indicator

Using the standard values of corresponding weighting coefficients, we calculate the cumulative indicators of economic security components according to Formula 21 (Tab. 3).

Table 3. Cumulative indicators of economic security

\begin{tabular}{|l|c|c|}
\hline Subindexes of economic security & $\begin{array}{c}\text { The value of the } \\
\text { weighting coefficient }\end{array}$ & $\begin{array}{c}\text { Normalized value } \\
\text { of the coefficient }\end{array}$ \\
\hline Industrial safety & 0,1218 & 22,90 \\
\hline Demographic security & 0,0913 & 63,27 \\
\hline Energy security & 0,1148 & 2,00 \\
\hline Foreign economic security & 0,1095 & 21,67 \\
\hline
\end{tabular}




\begin{tabular}{|l|c|c|}
\hline Subindexes of economic security & $\begin{array}{c}\text { The value of the } \\
\text { weighting coefficient }\end{array}$ & $\begin{array}{c}\text { Normalized value } \\
\text { of the coefficient }\end{array}$ \\
\hline Investment and innovation security & 0,1089 & 70,03 \\
\hline Macroeconomic security & 0,1224 & 10,49 \\
\hline Food security & 0,1007 & 1,80 \\
\hline Social security & 0,1013 & 4,56 \\
\hline Financial security & 0,1294 & 70,49 \\
\hline
\end{tabular}

The cumulative indicator of Ukraine's general economic security is calculated according to the formula:

$I=\sum_{m}\left(W F_{m} \times I_{m}\right)$,

where $W F m$ is a weighting factor that determines the degree of contribution of the indicator . of the $\mathrm{m}$-th sphere of economic security to the integrated index of economic security of Ukraine; Im - aggregate indicator of the $\mathrm{m}$-th sphere of economic security.

The calculations to Formula 22 show that cumulative indicator of Ukraine's general economic security equals 29.8 points.

The proposed calculation of the cumulative indicator of economic security enables analyzing economic security in terms of the most significant indicators of economic security components. This allows proposing measures to ensure a timely response and adequate management of these factors as efficiently as possible without any complicated calculations.

If we study the changes in the cumulative indicator value in real time, we can identify the factors that have the most significant impact on the detection of negative trends in the long run.

In the context of undetermined accelerating globalization of the global economy, in the EU in particular, we propose a scientific and methodological approach to assessing economic security in terms of its main indicators. We believe that due to cooperation with the EU, Ukraine's economic security is already positively effected. The Association Agreement offer great possibilities for Ukraine's development. The use of these opportunities in the context of globalization, creation and implementation of viable solutions will ensure equal cooperation. To develop together and enjoy mutual security, it should become one of the priorities of Ukraine's economic and political modernization.

\section{Discussion of the Results of the Study of Methodological Approaches and Calculations of Economic Security Indicators}

Studying the works of economists on the problems of national security in the context of national economy globalization allowed identifying the parameters of evolution of the "economic security" term and considering its main aspects. This allowed us to identify the problematic aspects of modern concepts of economic security. They are mainly based on the positions of the Soviet school of economics and are hardly relevant to the modern concepts of economic neoliberalism. Basically, it is because of the fact that the interests of national governments actually conflict with the interests of supranational corporations and financial organizations when they implement the economic security system. The national economies are already included in the global market, whether they 
want it or not. With due regard to such a political and economic environment, the concept of ensuring the national economic security should be the ideological basis for the development of economic policy in the countries with a debilitated transition economy.

Being a country with transition economy, Ukraine depends on the external economic conditions. We emphasize the need for the use of all possible tools to study the current state of national economic security. Based on such calculations, there is a real possibility to improve economic security, which will reduce dependence and attract investment.

These calculations show a real possibility to improve the long-term economic security. The presented method of calculating the cumulative indicator of Ukraine's economic security adequately describes the current state of national economy and can be practically applied by domestic and foreign government bodies to analyze critical vulnerabilities of national economic security.

At the same time, further research, especially dealing with the development of practical mechanisms to respond to identified threats to the national economic security, continues to be relevant.

\section{Conclusion}

The problem of ensuring the country's sustainable economic security is currently being studied in the aspect of specific economic calculations aimed at a timely response to external and internal risks and protection of the country's economic interests. With due regard to the most important approaches of economists to the study of economic security, we believe that the most relevant approach is the description of economic security as a set of conditions necessary to ensure the normal course of economic development and restore the development gap between the European countries and Ukraine integrating into the EU. The conditions which are crucial for the analysis of opportunities of improving the national economic security have been identified.

In the context of modern realities, the national security is not possible without an acceptable level of economic security. According to the system used by the authors, the current values of specified indicators have been calculated; their comparison with the corresponding standard values enables analyzing various components of Ukraine's economic security. Obviously, some of the identified economic factors are sources of danger and risk. But the system security depends on the ability to respond in a timely manner and adequately manage these factors as efficiently as possible, maximizing the positive effects and mitigating or even neutralizing the negative ones.

\section{References}

Taranych, O.V. (2016). Features of formation of competitive advantages of the developed countries in the world market. Ekonomika i orhanizatsiia upravlinnia: Zbirnyk naukoyykh prats. Vinnytsia: DonNU. Vyp. 3 (23). p. 317-326.

Tamošiūnienè, Rima \& Munteanu, Corneliu. (2015). Current research approaches to economic security. p. 6265. DOI:10.4995/ICBM.2015.1537.

Lima, de, Miranda, K., Snower, D.J. (2020). Recoupling Economic and Social Prosperity. Global Perspectives. 1 (1): 11867. DOI: 10.1525/001c.11867. 
Wolfers, A. (1952). National Security as an Ambiguous Symbol. In: Political Science Quarterly. vol. 67. nr. 4, p. 485.

Hager, Wolfgang (1980). Europas wirtschaftliche Sicherheit. Wirtschaftsdienst. Verlag Weltarchiv, Hamburg, Vol. 60, Iss. 9, pp. 456-461. ISSN 0043-6275.

Leszczyński, M. (2019). Bezpieczeństwo ekonomiczne, zmiany klimatyczne, wyzwania. Ante Portas - Studia nad Beapieczeństwem. Nr 1(12). p. 67-79. DOI: 10.33674/2201910.

Gębska, M. (2018). Współczesne bezpieczeństwo ekonomiczne i społeczno-kulturowe:Wymiar międzynarodowy. Warszawa:Akademia Obrony Narodowej. 510 p.

Andruseac, G. (2015). Economic security - new approaches in the context of globalization. CES Working Papers. Centre for European Studies, Alexandru Ioan Cuza University. vol. 7(2). p. 232-240.

Mihai, C., Pişleag, A. (2013). Norme juridice şi domenii de securitate. În: Revista de investigare a criminalităţii. Anul VI. nr. 1. EdițieSpecială, p. 96-98.

Repciuc T. Conceptele securităţii. Bucureşti: AXIOMA PRINT, 2008. 100 p.

Napalkova, Y.G. (2000). Economic security: institutional and legal analysis. Monograph. Rostov-na-Donu. 148 p.

Bai, Shi. (2002). Summary of Discussions on National Economic Security Issues[]. Economic Theory and Economic Management. (11). p. 75-79. (In chinese).

Letiche, J.M. (1969). The History of Economic Thought in the International Encyclopedia of the Social Sciences. Journal of Economic Literature. vol. 7. no. 2. p. 406-425.

Nee, V., Swedberg, R. (2008). Economic Sociology and New Institutional Economics. In: Ménard C., Shirley M.M. (eds) Handbook of New Institutional Economics. Springer, Berlin. Heidelberg. DOI: 10.1007/978-3-540-69305-5_30.

Harrison, C., White. (2002). Markets from Networks: Socioeconomic. Models of Production. Princeton. NJ.: Princeton. University Press. 389 p.

Băhnăreanu, C. (2006). Impactul factorilor economici asupra securității. În: Tendinţe inovatoare în economia şi managementul apărării. Sesiunea de comunicări şstïnțifice a departamentului regional de studii pentru managementul resurselor de apărare - 15 decembrie 2006, Braşov. Bucureşti: Editura Universităţii Naţionale de Apărare „CAROLI”. p. 21-26.

Sievidova, I. (2018). Factors affecting the functioning of wholesale markets for vegetable products. Agrosvit. vol. 2. p. 28-32.

Sievidova, I. and Plihun, S. (2018). Problematic aspects of the conjuncture agricultural market research in Ukraine. Agrosvit. vol. 15-16. p. 52-55.

Xiao, S.S. \& Park,B.I. (2018), Bring institutions into FDI spillover research: exploring the impact of ownership restructuring and institutional development in emerging economies. International Business Review. 27, 289-308.

Wehre, F. \& Pohl, J. (2016). Investment policies related to national security: a suvey of country practices. OECD working papers on international investment. Paris: OECD Publishing. DOI: 10.1787/5jlwrrf038nx-en.

Gribincea, A., Golovataia, L., Brovca, Gh. (2014). Economie mondială, migrația şi securitatea economică. Chişinău: IRIM. 306 p.

Milberg, William \& Winkler, Deborah. (2009). Globalization, Offshoring and Economic Insecurity in Industrialized Countries. DESA Working Paper. No. 87.35 p.

Sievidova, Iryna (2018). Formation of research-based strategies for the use of instruments of non-cooperative game theory. Efektyuna ekonomika. vol. 3. URL: http://www.economy.nayka.com.ua/?op=1\&z=6282 (Accessed $07 \mathrm{Feb} 2021)$.

Kyrylov, Yu.E. (2016). The impact of globalization on the development of national economies. vol. 12. URL: http://www.economy.nayka.com.ua/ ?op=1\&z=5297 (Accessed 07 Feb 2021).

Eurostat. 2019. Official site. URL: http://epp.eurostat.ec.europa.eu/portal/ page/portal/statistics/search_database.

Directory of the National Bank. (2019). Official site. URL: http://www.bank.gov.ua/control/uk/publish.

Normative publications of the State Statistics Service of Ukraine. (2019). Official site. URL: http://www.ukrstat.gov.ua.

UNCTADstat. (2019). Official site. URL: http://unctadstat.unctad.org/ ReportFolders/reportFolders.aspx.

Dynamics of the balance of payments (since 1998) (2020). National Bank. Official site. URL: http: //www.bank.gov.ua/control/uk/publish/category? cat_id $=44464$. 
Labor cost index - recent trends. 2019. Eurostat. Official site. URL: http://epp.eurostat.ec.europa.eu/statistics_explained/index.php.

Statistical materials of Ukraine. (2019). Ministry of Finance. Official site. URL: http://www.minfin.gov.ua/control/uk/publish/archive/ main?cat_id=325755. 